\title{
MENINGKATKAN HASIL BELAJAR PKn MATERI LEMBAGA NEGARA SESUAI UUD 1945 SERTA HASIL AMANDEMEN MELALUI PENERAPAN STRATEGI BELAJAR PETA KONSEP PADA SISWA KELAS VI SD NEGERI 1 TALATA
}

\author{
Musnianingsi ${ }^{1)}$, Sakka Hasan ${ }^{1)}$, Lisnawati Rusmin ${ }^{1)}$ \\ ${ }^{1)}$ Jurusan Pendidikan Guru Sekolah Dasar \\ FKIP Universitas Halu Oleo \\ email:musnianingsi.pjj@gmail.com
}

\begin{abstract}
Abstrak: Rumusan masalah dalam penelitian ini adalah apakah strategi belajar peta konsep dapat meningkatkan hasil belajar PKn siswa, aktivitas mengajar guru dan aktivitas belajar siswa pada materi Lembaga Negara Sesuai UUD 1945 serta Hasil Amandemen di kelas VI SDN 1 Talata Kabupaten Kolaka Timur. Tujuan penelitian ini adalah untuk meningkatkan hasil belajar siswa, aktivitas mengajar guru dan aktivitas belajar siswa pada materi Lembaga Negara Sesuai UUD 1945 serta Hasil Amandemen melalui penerapan strategi belajar peta konsep di kelas VI SDN 1 Talata Kabupaten Kolaka Timur. Jenis penelitian ini adalah penelitian tindakan kelas, terdiri dari dua siklus yang setiap siklusnya terdiri dari dua kali pertemuan. Prosedur penelitian ini meliputi: perencanaan, pelaksanaan tindakan, observasi dan evaluasi, dan refleksi. Teknik pengumpulan data dalam penelitian ini menggunakan lembar observasi, dan evaluasi tes siklus. Teknik analisis data dalam penelitian ini menggunakan analisis deskriptif yaitu menghitung persentase aktivitas guru, aktivitas siswa dan ketuntasan hasil belajar siswa selama proses pembelajaran. Berdasarkan hasil analisis dan pembahasan, menunjukkan bahwa pada siklus I terdapat 11 dari 22 siswa yang telah mencapai nilai $\geq 70$ dengan persentase ketuntasan 50\% dengan nilai rata-rata 65,3, dan pada siklus II terdapat 18 dari 22 siswa yang telah mencapai nilai $\geq 70$ dengan persentase ketuntasan $81,8 \%$ dengan nilai rata-rata 75,1 . Disimpulkan bahwa melalui penerapan strategi belajar peta konsep dapat meningkatkan hasil belajar PKn siswa pada materi Lembaga Negara Sesuai UUD 1945 serta Hasil Amandemen di kelas VI SDN 1 Talata Kabupaten Kolaka Timur.
\end{abstract}

Kata Kunci: Model Pembelajaran, Peta Konsep, Hasil Belajar, PKn

\begin{abstract}
The formulation of the problem in this research was "whether the Mapping Concept strategy can improve students' learning outcome in the Civic Education Subject, teacher's teaching activities and students' learning activities for material of the State Institution in accordance with the 1945 Constitution and Amendment Results at Class VI of SDN 1 Talata East Kolaka Regency? The purpose of this research was to improve the students' learning outcomes, teacher's teaching activities and students' learning activities on the State Institution Material in accordance with the 1945 Constitution and Amendment Results through the application of Mapping Concept strategy at the Class VI of SDN 1 Talata East Kolaka Regency. This research was a classroom action research which consisted of two cycles, each cycle consisted of two meetings. The procedures of this research were planning, implementing the actions, observing and evaluating, and reflecting. Technique of data collection in this research used observation sheet and evaluation test in each cycle. Technique of data analysis used descriptive analysis which was calculated on the percentage of teacher's teaching activity, students' learning activity and completeness of student learning outcomes during the learning process. Based on the data analysis and discussion, it showed that in the Cycle I, there were 11 students from 22 students who achieved the score $\geq 70$ with the percentage of success were $50 \%$ and the average score was 65.3. Then, in the Cycle II, there were 18 students from 22 students who achieved the score $\geq 70$ with the percentage of success were $81.8 \%$ and the average score was 75.1 . Furthermore, it was concluded that through the application of the Mapping Concept strategy, it could improve the students' learning outcomes in the Civic Education Subject for the the State Institution Material in accordance with the 1945 Constitution and Amendment Results at the Class VI of SDN 1 Talata East Kolaka Regency.
\end{abstract}

Keywords: Learning Model; Mapping Concept; Learning Outcomes; 
Jurnal Ilmiah Pembelajaran Sekolah Dasar

Volume 1 Nomor 2 - Agustus 2019,e-ISSN 26560402

Available online at:http://ojs.uho.ac.id/index.php/jipsd

\section{Pendahuluan}

Peningkatan mutu pendidikan selalu menjadi prioritas dalam pembangunan nasional, karena dengan pendidikan bermutu akan mampu mengembangkan potensi peserta didik untuk menghadapi dan memecahkan problematika kehidupan yang dihadapinya. Pendidikan yang bermutu tidak pernah terlepas dari peranan guru dalam pembelajaran. Pembelajaran yang semata-mata berfokus pada guru akan berimplikasi pada kinerja siswa. hal ini akan mengakibatkan berbagai kesulitan belajar yang pada gilirannya dapat mempengaruhi hasil belajar siswa (Tim Pengembang Ilmu Pendidikan, 2007, p.9). Seperti halnya yang terjadi pada SD Negeri 1 Talata, pembelajaran masih berfokus pada guru sehingga berdampak pada pencapaian hasil belajar siswa yang tidak maksimal sesuai dengan hasil observasi yang dilakukan di kelas VI SD Negeri 1 Talata Kabupaten Kolaka.

Berdasarkan hasil observasi di kelas VI SD Negeri 1 Talata menunjukkan bahwa ketuntasan hasil belajar PKn siswa semester ganjil tahun ajaran 2015/2016 pada materi Lembaga Negara Sesuai UUD 1945 serta Hasil Amandemen mencapai 68\% dengan nilai rata-rata 58,2. Nilai tesebut masih rendah dibandingkan standar KKM yang ditetapkan di sekolah yakni minimal 80\% siswa memperoleh nilai $\geq 70$.

Oleh karena itu, untuk mendapat hasil belajar yang maksimal kiranya perlu diterapkan strategi belajar peta konsep. Penerapan strategi pembelajaran ini mempunyai keuntungan antara lain cepat dan mudah dikuasai oleh siswa dalam penerapannya di lingkungan belajar kelas dalam proses pembelajaran. Di samping itu strategi ini dapat melatih siswa secara langsung mengenai pengembangan makna informasi baru yang didapatkan sehingga siswa lebih kreatif lagi dalam proses penyerapan materi pelajaran.

Berdasarkan keunggulan strategi belajar peta konsep diyakini bahwa hasil belajar tersebut masih dapat ditingkatkan. Oleh karena itu perlu dilakukan penelitian dengan judul "Meningkatkan Hasil Belajar PKn Materi Lembaga Negara Sesuai UUD 1945 serta Hasil Amandemen Melalui Penerapan Strategi Belajar Peta Konsep Pada Siswa Kelas VI SD Negeri 1 Talata Kabupaten Kolaka Timur"

Darlina (2011) dengan judul Penelitian Peningkatan Hasil Belajar Siswa Materi Perumusan Pancasila Melalui Penerapan Strategi Belajar Peta Konsep di Kelas VI SDN Inpres Wuyuneri Kabupaten Kolaka Utara. Hasil penelitian yang diperoleh pada siklus I sebanyak 14 siswa yang tuntas atau sebesar 70\% dan siklus II sebanyak 19 siswa yang tuntas atau sebesar 95\%. Peneliti menyimpulkan bahwa hasil belajar siswa materi Perumusan Pancasila di kelas VI SDN Inpres Wuyuneri dapat ditingkatkan melalui penerapan strategi belajar peta konsep. Masniah (2010) dengan judul penelitian Penerapan Strategi Belajar Peta Konsep untuk Meningkatan Hasil Belajar PKn Siswa pada Materi Keputusan Bersama di Kelas V SDN 1 Konda Kabupaten Konawe Selatan. Pada siklus I ketuntasan siswa mencapai 68\% (17 siswa tuntas) dan pada siklus II ketuntasan belajar siswa mencapai 88\% (22 siswa tuntas). Disimpulkan bahwa penerapan strategi belajar peta konsep untuk meningkatan hasil belajar PKn Siswa pada materi keputusan bersama di kelas V SDN 1 Konda Kabupaten Konawe Selatan.

Pemetaan konsep menurut Martin dalam Trianto (2010, p.157), merupakan inovasi baru yang penting untuk membantu anak menghasilkan pembelajaran bermakna dalam kelas. Peta konsep menyediakan bantuan visual konkret untuk membantu mengorganisasikan informasi sebelum informasi tersebut dipelajari. Para guru telah menggunakan peta konsep menemukan bahwa peta konsep member mereka basis logis untuk memutuskan ide-ide utama apa yang akan dimasukkan atau dihapus dari rencana-rencana dan pengajaran sains mereka. Peta konsep membantu guru memahami macam-macam konsep yang ditanamkan di topik lebih besar yang diajarkan.

Masalah dalam penelitian ini adalah apakah strategi belajar peta konsep dapat meningkatkan hasil belajar PKn siswa, aktivitas mengajar guru dan aktivitas belajar siswa pada materi Lembaga Negara Sesuai UUD 1945 serta Hasil Amandemen di kelas VI SDN 1 Talata Kabupaten Kolaka Timur?. Tujuan penelitian ini adalah untuk meningkatkan hasil belajar siswa, aktivitas mengajar guru dan aktivitas belajar siswa pada materi Lembaga Negara Sesuai UUD 1945 serta Hasil Amandemen melalui penerapan strategi belajar peta konsep di kelas VI SDN 1 Talata Kabupaten Kolaka Timur.

\section{Metode Penelitian}


Penelitian ini termasuk dalam jenis penelitian tindakan kelas. Karateristik yang khas dari penelitian tindakan kelas yakni adanya tindakan-tindakan (aksi) tertentu untuk memperbaiki proses belajar mengajar di kelas. Dalam penelitian tindakan kelas ini penelitian merencakan dua siklus dan tiap siklus terdiri dari dua kali pertemuan (Yuliawati F., 2012, p.17). Penelitian tindakan kelas ini telah dilaksanakan pada semester ganjil Tahun Pelajaran 2016/2017 di kelas VI SD Negeri 1 Talata Kabupaten Kolaka Timur. Subyek dalam penelitian ini adalah guru dan siswa yang berjumlah 22 orang yang terdiri dari 10 orang siswa laki-laki dan 12 orang siswa perempuan. Faktor-faktor yang diteliti dan diukur dalam penelitian ini adalah guru, siswa, dan hasil belajar. Penelitian tindakan kelas ini terdiri dari 2 (dua) siklus. Tiap siklus terdiri dari dua kali pertemuan yang dilaksanakan berdasarkan indikator yang ingin dicapai pada setiap faktor yang akan diselidiki. Siklus penelitian tindakan kelas setiap siklus terdiri dari perencanaan, implementasi tindakan, observasi dan analisis dan refleksi. Data dalam penelitian ini berupa data kualitatif meliputi observasi aktivitas siswa dan aktivitas guru dengan strategi belajar peta konsep dan data kuantitatif berupa hasil belajar siswa. Data dalam penelitian ini bersumber dari siswa dan guru. Teknik pengumpulan data dalam penelitian ini melalui pemberian tes hasil belajar pada siswa diakhir siklus menggunakan tes hasil belajar dan melalui pengamatan aktivitas mengajar guru dan aktivitas belajar siswa menggunakan lembar observasi aktivitas mengajar guru dan aktvitas belajar siswa.

Data yang diperoleh dalam penelitian ini dianalisis dengan menggunakan analisis deskriptif yang dimaksudkan untuk memberikan gambaran distribusi hasil belajar siswa yang diajar dengan menggunakan strategi belajar peta konsep.

Adapun rumus yang digunakan sebagai berikut:

1. Menghitung tingkat pencapaian ketuntasan belajar:

$$
\text { Secara individual \% TB }=\frac{\text { Nilai yang di capai }}{\text { Nilai Ideal }} \times 100 \%
$$

2. Menentukan persentase ketuntasan :

$\% \mathrm{~TB}=\frac{\Sigma \mathrm{TB}}{\mathrm{n}} \times 100 \%$

Keterangan :

$\sum \mathrm{TB}=$ Jumlah siswa tuntas belajar

$\mathrm{n} \quad=$ Jumlah siswa secara keseluruhan $\quad$ (Usman, 2001, p.139)

3. Menentukan rata-rata skor aktivitas siswa

$$
\overline{\mathrm{X}}=\frac{\sum \mathrm{Xi}}{\mathrm{n}}
$$

di mana :

$\overline{\mathrm{X}} \quad=$ Nilai rata-rata yang diperoleh.

$\Sigma \mathrm{xi}=$ Jumlah nilai yang diperoleh setiap kelompok.

$\mathrm{n} \quad=$ Jumlah kelompok secara keseluruhan.

Indikator keberhasilan tindakan pembelajaran dalam penelitian ini adalah ketuntasan belajar siswa dikatakan berhasil jika minima $80 \%$ siswa dari keseluruhan siswa memperoleh skor $\geq 70$, ketuntasan aktivitas mengajar guru tercapai jika minimal $80 \%$ telah terlaksana sesuai skenario pembelajaran dan ketuntasan aktivitas belajar siswa tercapai jika minimal $80 \%$ telah terlaksana sesuai skenario pembelajaran.

\section{Hasil Penelitian}

Kegiatan yang dilakukan sebelum melaksanakan penelitian yaitu peneliti mengidentifikasi permasalahan pembelajaran PKn yang terjadi di kelas VI SD Negeri 1 Talata, dengan bekerjasama dengan guru PKn di sekolah tersebut. Peneliti melakukan observasi awal terhadap pelaksanaan pembelajaran yang dilakukan guru PKn dalam pembelajaran di kelas, yang diamati oleh peneliti dengan tujuan untuk mengetahui kendala-kendala yang terjadi dalam pembelajaran. Dari data hasil observasi awal tersebut 
terungkap bahwa pembelajaran PKn di kelas pada dasarnya belum melibatkan siswa secara aktif dalam proses belajar, sehingga mengakibatkan siswa kurang memahami materi yang disampaikan guru.

Selain mengamati aktivitas guru dan siswa dalam pembelajaran PKn, peneliti juga memperoleh data awal hasil belajar siswa terhadap materi PKn pada semester ganjil tahun ajaran 2015/2016. Dari data hasil belajar siswa tersebut terungkap bahwa hasil belajar siswa terhadap mata pelajaran PKn rendah khususnya terhadap materi Lembaga Negara Sesuai UUD 1945 Serta Hasil Amandemen dalam kategori rendah dengan ketuntasan 68\%. Kondsisi ini masih belum mencapai KKM yang ditetapkan di sekolah yaitu minimal $80 \%$ siswa memperoleh nilai $\geq 70$.

Dari hasil observasi, peneliti menganggap perlu melakukan tindakan alternatif untuk mengatasi permasalahan tersebut peneliti melakukan penelitian tindakan kelas dengan menerapkan strategi belajar peta konsep yang lebih mengutamakan keaktifan siswa dan memberi kesempatan kepada siswa untuk mengembangkan potensinya secara maksimal. Sebelum pelaksanaan tindakan, peneliti menjelaskan tentang prinsip pembelajaran PKn dengan menggunakan strategi belajar peta konsep kepada guru kelas VI dan mendiskusikan jadwal pelaksanaan tindakan. Peneliti memberikan rencana perbaikan pembelajaran (RPP) dan lembar observasi yang telah disusun kepada guru PKn di kelas VI sebagai instrument dalam melakukan pengamatan selama penelitian berlangsung.

\section{Aktivitas Mengajar Guru}

Mengajar pada dasarnya, meliputi mengajari siswa bagaimana belajar, mengingat, berpikir dan bagaimana memotivasi diri sendiri (Weisten dan Meyer dalam Nur, 2000: 9). Adapun kegiatan aktivitas mengajar guru pada siklus I pertemuan pertama yaitu dari 11 aspek yang diamati, pada pertemuan pertama terlaksana hanya 6 skenario pembelajaran, sedangkan pada pertemuan kedua terlaksana hanya 8 skenario pembelajaran. Jadi, KAMG pada pertemuan pertama sebesar 54,5\% dan pertemuan kedua 72,7\% sehingga rata-rata persentase aktivitas mengajar guru siklus I adalah 63,6\%. pada siklus II pertemuan pertama yaitu dari 11 aspek yang diamati, pada pertemuan pertama terlaksana hanya 10 skenario pembelajaran, sedangkan pada pertemuan kedua seluruh aspek dalam skenario pembelajaran terlaksana 11 aspek. Jadi, KAMG pada pertemuan pertama sebesar 90,9\% dan pertemuan kedua $100 \%$ sehingga ratarata persentase aktivitas mengajar guru siklus II adalah 95,45\%. Peningkatan aktivitas mengajar guru dapat dilihat pada grafik berikut:

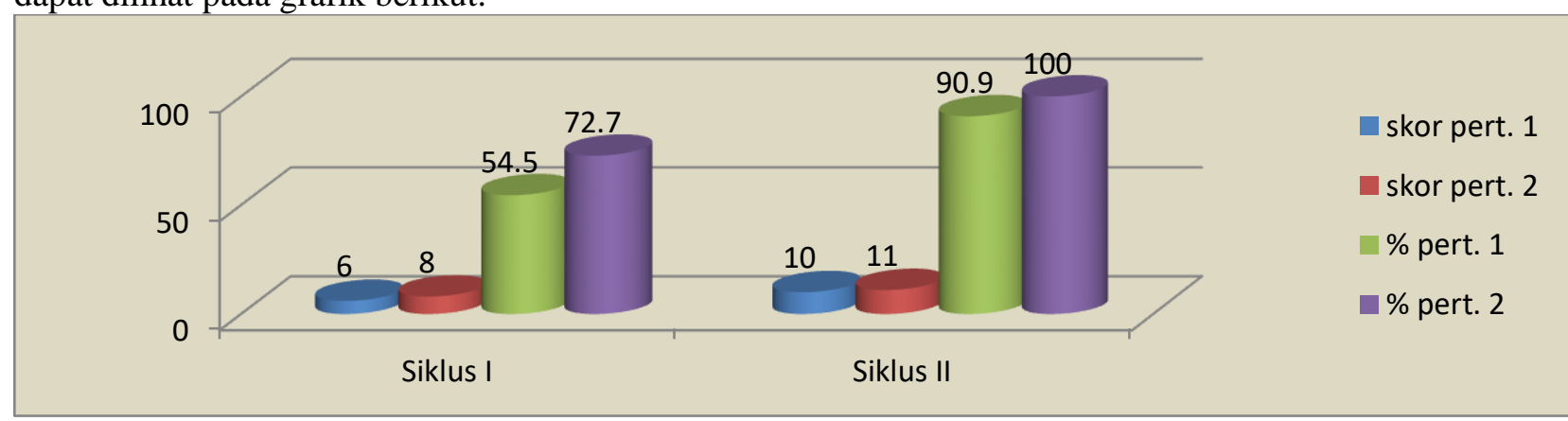

Gambar 1. Grafik Peningkatan Aktivitas Mengajar Guru

Berdasarkan grafik di atas, menunjukkan bahwa skor perolehan guru pada siklus I pertemuan pertama adalah 6 dan pertemuan kedua 8, siklus II pertemuan pertama adalah 10 dan pertemuan kedua adalah 11. Persentase keberhasilan aktivitas mengajar guru pada siklus I pertemuan pertama adalah $54,5 \%$ dan pertemuan kedua $72,7 \%$. Persentase keberhasilan aktivitas mengajar guru pada siklus II pertemuan pertama meningkat menjadi $90,9 \%$ dan pertemuan kedua $100 \%$.

\section{Aktivitas Belajar Siswa}

Aktivitas belajar siswa pada siklus I pertemuan pertama dari 11 skor maksimal pada aspek yang diamati yang terlaksana hanya 6 aspek sedangkan pada pertemuan kedua yang terlaksana hanya 8 aspek. 
Jadi, persentase aktivitas belajar siswa siklus I pertemuan pertama sebesar 54,5\% dan pertemuan kedua $72,7 \%$ sehingga rata-rata aktivitas belajar siswa siklus I adalah $63,6 \%$. pada siklus II pertemuan pertama dari 11 aspek yang diamati yang terlaksana hanya 9 aspek sedangkan pada pertemuan kedua 11 aspek terlaksana. Jadi, persentase aktivitas belajar siswa pada siklus I pertemuan pertama sebesar $81,8 \%$ dan pertemuan kedua 100\% sehingga rata-rata aktivitas belajar siswa pada siklus II adalah 90,9\%. Peningkatan aktivitas belajar siswa dapat dilihat pada grafik berikut:

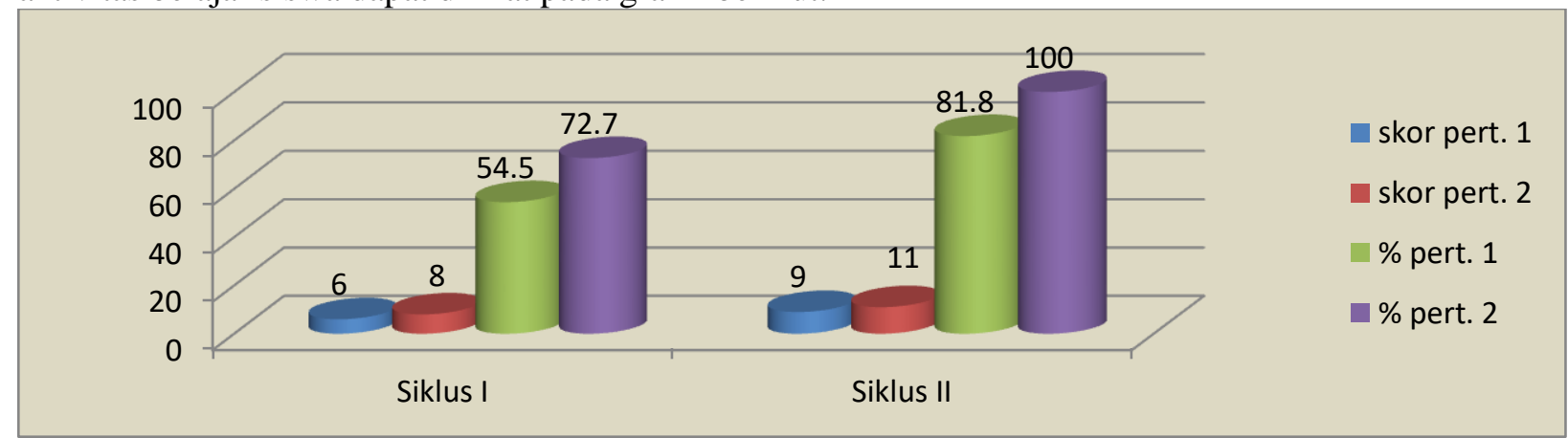

Gambar 2. Grafik Peningkatan Aktivitas Belajar Siswa

Berdasarkan grafik di atas, menunjukkan bahwa skor perolehan siswa pada siklus I pertemuan pertama adalah 6 dan pertemuan kedua 8, siklus II pertemuan pertama adalah 9 dan pertemuan kedua 11 . Persentase keberhasilan aktivitas belajar siswa pada siklus I pertemuan pertama adalah 54,5\% dan pertemuan kedua $72,7 \%$. Persentase keberhasilan aktivitas belajar siswa pada siklus II pertemuan pertama meningkat menjadi $81,8 \%$ dan pertemuan kedua $100 \%$.

\section{Hasil Belajar Siswa}

Hasil belajar merupakan kebulatan pola tingkah laku manusia yang terdiri dari sejumlah aspek yang akan tampak pada setiap perubahan pada aspek-aspek, seperti pengetahuan, pengertian, kebiasaan, keterampilan, apresiasi, emosional, hubungan sosial, jasmani, budi pekerti, dan sikap (Hamalik, 2003, p.30). Hasil tes siswa tentang materi yang telah diajarkan masih tergolong rendah karena belum memenuhi standar ketuntasan minimal yang ditetapkan oleh sekolah yakni $80 \%$ siswa telah mencapai nilai $\geq 70$. Hasil evaluasi siklus I, siswa yang memperoleh nilai $\geq 70$ sebanyak 11 orang dari 22 orang siswa atau sebesar 50\% dengan nilai rata-rata 65,3. Melihat hasil belajar siswa yang belum mencapai standar ketuntasan pada siklus I ini, maka pembelajaran PKn tentang materi Lembaga Negara Sesuai UUD 1945 Serta Hasil Amandemen melalui strategi belajar peta konsep masih harus dilanjutkan pada siklus ke II karena belum mencapai indikator keberhasilan sebesar $80 \%$. Hasil tes siklus II menunjukkan bahwa pemahaman siswa tentang materi yang telah diajarkan tersebut sudah memenuhi standar ketuntasan minimal yang telah ditetapkan oleh sekolah yakni $80 \%$ siswa telah mencapai nilai $\geq 70$. Hasil evaluasi siklus II siswa yang memperoleh nilai $\geq 70$ sebanyak 18 orang dari 22 orang siswa atau sebesar $81,8 \%$ dengan nilai rata-rata 75,1 , sedangkan siswa yang memperoleh nilai di bawah 70 sebanyak 4 orang siswa atau sebesar $18,2 \%$.

Hasil analisis ketuntasan belajar siswa pada siklus I dan siklus II menunjukkan peningkatan. Peningkatan hasil belajar siswa dapat dilihat pada grafik berikut: 


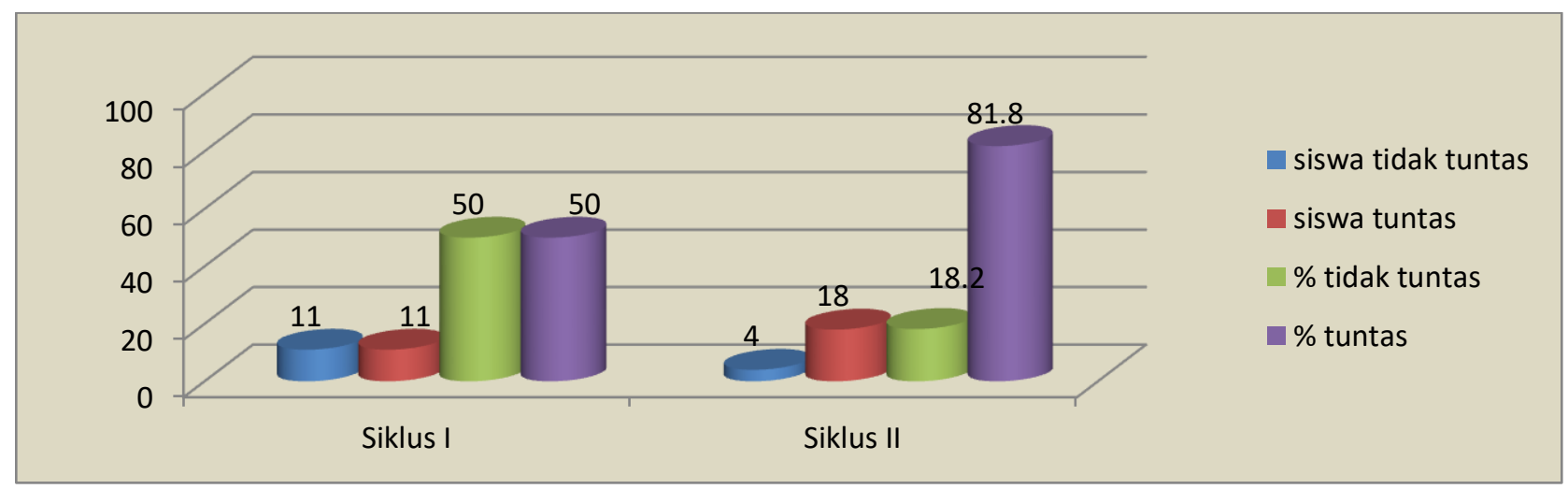

Gambar 1. Grafik Peningkatan Ketuntasan Hasil Belajar Siswa

Berdasarkan grafik di atas, menunjukkan bahwa pada pembelajaran siklus I, siswa yang memperoleh nilai antara 0-69 berjumlah 11 orang siswa (50\%), siswa yang memperoleh nilai rentang 70100 berjumlah 11 orang siswa $(50 \%)$. Pada pembelajaran siklus II, siswa yang memperoleh nilai antara 0 69 berjumlah 4 orang $(18,2 \%)$, siswa yang memperoleh nilai rentang 70-100 berjumlah 18 orang $(81,8 \%)$. Ketuntasan belajar siswa mencapai $81,8 \%$, dimana siswa yang memperoleh nilai $\geq 70$ berjumlah 18 orang siswa sedangkan 4 orang siswa belum mencapai ketuntasan belajar.

\section{Pembahasan}

Hasil belajar diperoleh melalui evaluasi atau penilaian yang merupakan tindak lanjut atau cara mengukur tingkat penguasaan siswa. Evaluasi atau tes yang diberikan setelah pembelajaran usai. Hal ini sejalan dengan pendapat Abdurrahman (dalam Jihad, 2010, p.14) menyatakan "hasil belajar adalah kemampuan yang diperoleh anak setelah melalui kegiatan belajar". Sedangkan menurut Juliah (dalam Jihad, 2010, p.15) menyatakan "hasil belajar adalah segala sesuatu yang menjadi milik siswa sebagai akibat dari kegiatan belajar yang dilakukannya".

Berdasarkan nilai yang diperoleh siswa, guru melakukan analisis untuk menentukan ketuntasan belajar siswa. Hasil analisis ketuntasan belajar siswa pada siklus I dan siklus II menunjukkan peningkatan dimana pembelajaran siklus I, siswa yang memperoleh nilai antara 0-69 berjumlah 11 orang siswa (50\%), siswa yang memperoleh nilai rentang 70-100 berjumlah 11 orang siswa (50\%). Pada pembelajaran siklus II, siswa yang memperoleh nilai antara 0-69 berjumlah 4 orang $(18,2 \%)$, siswa yang memperoleh nilai rentang 70-100 berjumlah 18 orang (81,8\%). Ketuntasan belajar siswa mencapai 81,8\%, dimana siswa yang memperoleh nilai $\geq 70$ berjumlah 18 orang siswa sedangkan 4 orang siswa belum mencapai ketuntasan belajar. Lyu \& Wang (2018, p.4) mengemukakan bahwa 'In addition accumulating knowledge and learning problem-solving capability, such a method stressed on the thinking process in learning to effectively enhance students' learning achievement and allowed learners generating various concepts to enhance learning autonomy and generalization'.

Selama proses pembelajaran peneliti mengadakan refleksi dengan observer untuk mengetahui kelemahan dan keberhasilan dalam proses pembelajaran. Hal-hal yang observasi aktivitas mengajar guru dan aktivitas belajar siswa pada proses pembelajaran. Hasil observasi aktivitas mengajar guru pada penelitian tindakan pembelajaran menjadi dasar untuk menentukan skor perolehan guru. Skor perolehan guru digunakan untuk menentukan persentase keberhasilan aktivitas mengajar guru. Peningkatan aktivitas mengajar guru menunjukkan bahwa skor perolehan guru pada siklus I pertemuan pertama adalah 6 dan pertemuan kedua 8, siklus II pertemuan pertama adalah 10 dan pertemuan kedua adalah 11. Persentase keberhasilan aktivitas mengajar guru pada siklus I pertemuan pertama adalah 54,5\% dan pertemuan kedua 72,7\%. Persentase keberhasilan aktivitas mengajar guru pada siklus II pertemuan pertama meningkat menjadi $90,9 \%$ dan pertemuan kedua $100 \%$. 
Jurnal Ilmiah Pembelajaran Sekolah Dasar

Volume 1 Nomor 2 - Agustus 2019,e-ISSN 26560402

Available online at:http://ojs.uho.ac.id/index.php/jipsd

Dengan adanya kekurangan-kekurangan yang terjadi pada tindakan siklus I, sehingga KAMG pada tindakan I pertemuan 1 hanya mencapai 54,5\% dari keseluruhan kegiatan pembelajaran dan pada pertemuan kedua hanya mencapai $72,7 \%$. Sebelum melaksanakan penelitian pada tindakan II, peneliti mengadakan refleksi bersama observer untuk memperbaiki kekurangan-kekurangan pada tindakan I.

Pada pelaksanaan tindakan II, keberhasilan aktivitas mengajar guru dan aktivitas belajar siswa sudah menggembirakan bagi peneliti, karena menurut hasil observasi pelaksanaan skenario pembelajaran pada pertemuan pertama aktivitas guru mencapai 90,9\% dan pada pertemuan kedua telah mencapai $100 \%$. Semua skenario dalam pembelajaran telah terlaksana dengan baik.

Siswa yang aktif baik secara individual maupun secara kelompok dapat menjadikan belajar lebih baik dan bermakna (Dimyati dan Mudjiono, 2000, p.12). Keberhasilan aktivitas belajar siswa menunjukkan peningkatan setelah penerapan strategi belajar peta konsep. Plotz (2019, p.1) mengemukakan bahwa 'In the majority of the existing literature the validity of concept maps is not questioned. Additionally, there are studies to support the hypothesis from above with empirical evidence'. Peningkatan aktivitas belajar siswa menunjukkan bahwa skor perolehan siswa pada siklus I pertemuan pertama adalah 6 dan pertemuan kedua 8, siklus II pertemuan pertama adalah 9 dan pertemuan kedua 11 . Persentase keberhasilan aktivitas belajar siswa pada siklus I pertemuan pertama adalah $54,5 \%$ dan pertemuan kedua $72,7 \%$. Persentase keberhasilan aktivitas belajar siswa pada siklus II pertemuan pertama meningkat menjadi $81,8 \%$ dan pertemuan kedua $100 \%$.

Keberhasilan aktivitas belajar siswa pada tindakan I pertemuan 1, dari 11 aspek pembelajaran yang terlaksana hanya 6 skenario pembelajaran dan pada pertemuan kedua hanya mencapai 8 aspek pembelajaran. Dengan demikian, maka KABS pertemuan 01 hanya mencapai $54,5 \%$ dan pertemuan 02 mencapai $72,7 \%$. Ketidakberhasilan aktivitas belajar siswa pada tindakan I disebabkan karena peneliti belum dapat menerapkan strategi belajar peta konsep dengan baik, dimana siswa dibiarkan sendiri-sendiri dalam mengerjakan tugas atau tidak membimbing kelompok dengan baik dan siswa masih merasa asing dengan belajar dalam kelompok sehingga belum dapat menyesuaikan diri dengan teman dalam kelompoknya. Hal-hal tersebut menyebabkan keaktifan siswa dalam bekerja sama dalam kelompok, partisipasi siswa dalam kelompok untuk menyelesaikan tugas, memberikan gagasan dalam menyelesaikan tugas, dan keberanian siswa dalam mengemukakan pendapat serta tanggung jawab siswa dalam kelompok, tidak sesuai dengan yang diharapkan dalam penerapan strategi belajar peta konsep. Setelah menerima saran-saran dari observer berdasarkan hasil diskusi pada kegiatan refleksi, maka peneliti mengadakan tindakan siklus II dengan penerapan strategi belajar peta konsep mata pelajaran PKn materi Lembaga Negara Sesuai UUD 1945 Serta Hasil Amandemen.

Aktivitas belajar siswa dalam kelompok pada tindakan II, sesuai dengan pengamatan peneliti melalui lembar pengamatan kerja kelompok telah berjalan dengan baik. Setiap anggota kelompok sudah dapat berpartisapasi dengan aktif, saling memberi gagasan dengan berbagi tugas dalam menyelesaikan LKS dengan penuh tanggung jawab dan siswa nampak ceria dalam bekerja. Dengan keberhasilan aktivitas mengajar guru dan aktivitas belajar siswa yang sudah cukup baik, maka mempengaruhi hasil belajar siswa.

Dari hasil evaluasi tersebut menunjukan bahwa usaha dan keberhasilan belajar dipengaruhi oleh berbagai faktor. Hal ini sesuai dengan yang dikemukakan oleh Syah (2010, p.132) bahwa hasil belajar dipengaruhi oleh beberapa faktor yaitu, faktor internal adalah faktor yang berasal dari diri siswa, faktor eksternal adalah faktor yang berasal dari luar diri siswa dan faktor pendekatan belajar yaitu jenis upaya belajar yang meliputi strategi dan metode yang digunakan untuk melakukan pembelajaran.

Karena indikator keberhasilan dalam penelitian ini telah tercapai dalam hal ini aktivitas belajar siswa selama proses pembelajaran sudah cukup baik dan minimal $80 \%$ siswa telah memperoleh nilai $\geq 70$. Maka, hipotesis tindakan dalam penelitian ini telah tercapai yaitu penerapan strategi belajar peta konsep dapat meningkatkan hasil belajar PKn siswa materi Lembaga Negara Sesuai UUD 1945 Serta Hasil Amandemen di Kelas VI SD Negeri 1 Talata .

\section{Simpulan}


1. Penerapan strategi belajar peta konsep dapat meningkatkan hasil belajar PKn pada materi Lembaga Negara Sesuai UUD 1945 Serta Hasil Amandemen pada siswa kelas VI SD Negeri 1 Talata. Hal ini dapat dilihat pada peningkatan hasil belajar siswa, pada siklus I rata-rata hasil belajar siswa adalah 65,3 dengan persentase ketuntasan klasikal sebesar 50\% sedangkan pada siklus II rata-rata hasil belajar siswa adalah 75,1 dengan persentase ketuntasan klasikal mencapai 81,8\%.

2. Berdasarkan hasil observasi pada siklus I dan siklus II persentase aktivitas guru dalam pembelajaran strategi peta konsep selalu meningkat, ini dapat dilihat dari pencapaian indikator. Pada siklus I aktivitas guru mencapai $54,5 \%$ pertemuan pertama dan $72,7 \%$ pada pertemuan kedua. Pada siklus II meningkat menjadi $90,9 \%$ dan $100 \%$ pada pertemuan kedua. Hal tersebut menunjukkan bahwa kegiatan mengajar guru dengan menggunakan strategi belajar peta konsep telah dilaksanakan dengan baik dan mencapai indikator kinerja.

3. Berdasarkan hasil observasi pada siklus I dan siklus II persentase aktivitas siswa setelah mengikuti pembelajaran strategi peta konsep yang diterapkan oleh guru mengalami peningkatan, yang terlihat dari pencapaian indikator yang sudah terpenuhi. Pada siklus I aktivitas siswa mencapai 54,5\% pertemuan pertama dan 72,7\% pada pertemuan kedua. Pada siklus II meningkat menjadi 81,8\% pada pertemuan pertama dan $100 \%$ pada pertemuan kedua. Hal tersebut menunjukkan bahwa siswa telah dapat mengikuti pembelajaran dengan menggunakan strategi belajar peta konsep dengan baik.

\section{Daftar Pustaka}

Darlina. 2011. Peningkatan Hasil Belajar Siswa Materi Perumusan Pancasila Melalui Penerapan Strategi Belajar Peta Konsep di Kelas VI SDN Inpres Wuyuneri Kabupaten Kolaka Utara. Skripsi. Kendari: Universitas Halu Oleo.

Dimyati dan Mudjiono, 2000. Belajar dan Pembelajaran. Rineka Cipta. Jakarta.

Hamalik, O., 2003. Perencanaan Pengajaran. Jakarta: Rineka Cipta.

Jihad A. dan Haris A., 2010. Evaluasi Pembelajaran. Yogyakarta: Multi Pressindo.

Lyu, Desheng \& Wang, Bei. 2018. Effects of the Application of Computer Network Technology to Guided Discovery Teaching on Learning Achievement and Outcome. EURASIA Journal of Mathematics, Science and Technology Education, 2018, 14(7), 3269-3276. https://doi.org/10.29333/ejmste/91249

Masniah. 2010. Penerapan Strategi Belajar Peta Konsep untuk Meningkatan Hasil Belajar PKn Siswa pada Materi Keputusan Bersama di Kelas V SDN 1 Konda Kabupaten Konawe Selatan. Skripsi. Kendari: Universitas Halu Oleo.

Nur, Mohamad, dkk. 2000. Pembelajaran Kooperatif. Surabaya: Universitas Press Unesa.

Plotz, Thomas. 2019. Are Concept Maps a Valid Measurement Toolfor Conceptual Learning? A Crosscase Study. EURASIA Journal of Mathematics, Science and Technology Education, 2020, 16(1), em1795. https://doi.org/10.29333/ejmste/110174

Syah, M., 2010. Psikologis Pendidikan. Bandung: Remaja Rosdakarya.

Tim Pengembang Ilmu Pendidikan, 2007. Ilmu dan Aplikasi Pendidikan. Bandung: PT. Imperial Bhakti Utama. 
Jurnal Ilmiah Pembelajaran Sekolah Dasar

Volume 1 Nomor 2 - Agustus 2019,e-ISSN 26560402

Available online at:http://ojs.uho.ac.id/index.php/jipsd

Trianto, 2010. Mendesain Model Pembelajaran Inovatif-Progresif. Surabaya: Kharisma Putra Utama.

Usman U. M., 2001. Menjadi Guru Profesional. Bandung: PT. Remaja Rosdakarya.

Yuliawati F., 2012. Penelitian Tindakan Kelas untuk Tenaga Pendidik Profesional. Yogyakarta: Pedagogia. 